\title{
Cover Illustration and Poem of Rūmī: The Vernal Friend's Return
}

The cover illustration on this issue of the Mawlana Rumi Review is by Esrafil Shirchi (Isrāfîl Shīrchī), an internationally renowned Persian calligrapher, awarded the prestigious rank of Master Calligrapher (Ustād) by the Association of Persian Calligraphers of Tehran (Anjuman-i Khushnivīsān-i Tihrān). ${ }^{1}$ This rendering depicts the verses from a ghazal in Rumi's Div ān-i Shams, that begins

\section{$\bar{A} b$ zanìd rāh rā hìn ki nigār mìrisad muzhda dahìd bāgh rā bū-yi bahār mīrisad ${ }^{2}$}

In the elegantly calligraphed Persian text of the poem seen on the cover, Rümì's verses dance across the page in a symbolic samā of the Shikasta-Nasta'ìq style, the choreographed script reflecting the rhythm and musicality of the original verses.

To quote Mr. Shirchi: 'The dancing lines are looking for their safe nest and the love which has illuminated their life is shining like the sun'. ${ }^{3}$ The editors at the Mawlana Rumi Review are grateful for Mr. Shirchi's permission to use this as the cover art for our journal.

An English translation of the poem follows:

1 See the Association's website at www.khoshnevisanetehran.com. Other examples of Mr. Shirchi's calligraphy may be seen here: https://tinyurl.com/IsrafilShirchi.

2 From Jalāl al-Dīn Rūmī, Kulliyāt-i Shams yā Dīwān-i kabìr, ed. Badī‘ al-Zamān Furūzānfar, 3rd printing (Tehran: Amīr Kabīr 1363 A.Hsh./1984), II, p. 56, ghazal 549, vv. 5836-43.

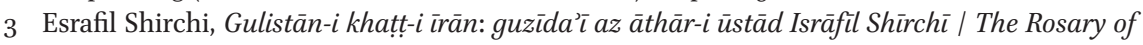
Persian Calligraphy (Tehran: Gooya House of Culture and Arts 2011), p. 1. The work on this cover issue appears on page 256 . 


\section{The Vernal Friend's Return \\ Translated by Franklin Lewis}

Water down the dusty road! Look! Quick!

Beauty's very picture, and here it comes our way!

Let the crier call glad-tidings to the garden:

here comes the fragrance of the spring!

Make way for the friend we love, that waxing full-form moon:

Here comes a global radiance, basking in that beaming face.

The heavens cleft asunder, a mighty clamor fills the world,

Ambergris and musk aflutter in the wind,

here come the regal streamers of the Friend!

The garden $\sim$ splendor ripening; the eyes $\sim$ delighted and illumined.

Sulking sorrow creeps aside,

and here is that celestial orb, ascendant at our side.

The unleashed arrow's speeding toward its target, and we're still sitting still?

Here comes the King to hunt!

The verdure bows in waves of salutation: Peace!

The cypress rises, rooted upright in salute

on foot, the shrubbery marches forward in formation,

and here there come the blossoms, riding on their mounts.

Those lucky ones, ensconced at ease, within the private canopy of sky,

what wines they slowly sip!

Their spirits are already smashed and wasted,

There goes their starried shooting reason - hung-over, drooping drunk.

As you enter in our cul-de-sac, you'll see silence is our habit, for talk and chatter with the likes of us kicks up dust and vapor. ${ }^{4}$

4 The translation, which previously appeared in Mawlana Rumi Review v (2014), p. 106, follows the text of Kulliyāt-i Shams yā Dīwān-i kabìr, ed. Badī` al-Zamān Furūzānfar, 3rd printing, (Tehran: Amīr Kabīr, ${ }_{3} 63$ A.Hsh./1984), II, p. 56, ghazal 549, vv. 5836-43. 